\title{
KONTRASTIVNA ANALIZA UZVIKA NA TALIJANSKOM I HRVATSKOM JEZIKU U WHATSAPP PORUKAMA
}

\author{
Danijela Berišić Antić \\ Sveučilište u Zadru
}

U ovom radu prikazana je kontrastivna analiza uzvika na hrvatskom i talijanskom jeziku s primjerima koji se koriste u WhatsApp porukama. Nakon uvodnog dijela koji se odnosi na dijakronijsku analizu navedene kategorije, slijedi analiza uzvika uz primjere pisanih poruka na oba jezika kako bi se istaknula njihova grafijska, semantička i sintaktička sličnost i razlika.

Analiza prikupljenih primjera provedena je tijekom akademske godine 2017./2018. na osnovi šezdeset ispitanika, u dobi od 20 do 25 godina koji žive u Hrvatskoj i Italiji. Dokazana je pretpostavka da većina ispitanika koristi uzvike u pisanom obliku imitirajući u grafijskom obliku govorni jezik. Isti uzvici nemaju uvijek jednako značenje u oba jezika, dok su semantička i sintaktička obilježja vrlo slična.

Ključne riječi: uzvici, kontrastivna analiza, hrvatski i talijanski jezik, WhatsApp poruke

\section{UVOD}

Tehnološki je napredak stvorio novu jezičnu stvarnost: jezik pisanih poruka u kojoj se odmiče od pravila pisanja karakterističnih za standardni jezik. "Digitalni okoliš" zamijenio je interpersonalnu, tj. tradicionalnu komunikaciju licem u lice posve novim vidom komunikacije bez mimike, gesta i drugih signala spajajući pojedinca sa svijetom. Usmenu komunikaciju zamjenjuje pisana koju karakterizira uporaba posebnog jezika mladih kao proizvoda njihove kreativnosti. Komunikacija pisanim porukama ima svoje prednosti, ali i nedostatke jer interpersonalno komuniciranje licem u lice sudionicima obično pruža velike mogućnosti za opažanje neverbalnog ponašanja koje je važno jer može nadopuniti, suprotstaviti, potencirati, regulirati ili poništiti verbalni sadržaj poruke (Reardon, 1998: 13), a u komunikaciji porukama neverbalni znakovi bivaju zamijenjeni interpunkcijskim znakovima i emotikonima koji nisu osobni i jedinstveni kao oni u komunikaciji koja se odvija uživo. Poslane poruke, koje oponašaju verbalnu i neverbalnu komunikaciju, često mogu biti krivo shvaćene posebice ako se ne zna dekodirati novi jezik elektroničke komunikacije ili ako se on

dantic@unizd.hr 
koristi na nerazumljiv način, a o posljedici loše komunikacije posvjedočili su i mnogi književnici: „,... tko ne zna komunicirati ili loše komunicira, nesretan je i širi osjećaj tuge oko sebe", , ako se osoba ne izražava na jasan način znači da nema uopće nikakve poruke. ${ }^{\text {. }}$ " „Jezik, čist materinji jezik poznavati je prva i najglavnija dužnost svakog pisca. Tko ga ne poznaje, može biti uman, odličan, zanimljiv čovjek, ali dobar, uspješan pisac - nikada. Pokažite mi na jednog jedinog većeg pisca u stranom svijetu što griješi proti pravilima svog jezika. ${ }^{2}$

U ovom radu naglasak je na analizi uzvika u WhatsApp porukama koji su izgubili svoje uobičajeno leksičko značenje, a određuju početak ili kraj neke razgovorne jedinice. Cilj je rada utvrđivanje glavnih obilježja ove kategorije na hrvatskom i na talijanskom jeziku na osnovi sličnosti i razlika u grafiji, kao i na semantičkom i sintaktičkom polju, a pretpostavlja se da ovakva vrsta uzvika ukazuje na vidljive razlike na grafijskoj razini te da se $\mathrm{u}$ oba jezika ističe velika semantička i sintaktička sličnost pri uporabi navedene jezične kategorije.

U neformalnoj pismenoj komunikaciji uzvici, koji se definiraju kao pojednostavljeni sintaktički nezavisni elementi i gramatički nepromjenjive vrste riječi, proširuju jezičnu izražajnost (Sironić-Bonefačić, 1996) i potrebno ih je zbog njihove učestalosti što više proučavati u nastavi talijanskog kao stranog jezika, jer se razumijevanjem njihova značenja, tj. uočavanjem njihove različitosti i otkrivanjem novonastalih oblika proširuje i komunikacijska kompetencija.

\section{DIJAKRONIJSKA ANALIZA UZVIKA I NJIHOVA KLASIFIKACIJA U HRVATSKIM I TALIJANSKIM GRAMATIKAMA}

U modernoj lingvistici, u usporedbi s drugim gramatičkim kategorijama, uzvici se općenito smatraju marginalnom pojavom pa su stoga i rijetko proučavani. Iako ne postoji jedinstvena definicija uzvika, moguće je utvrditi neke opće karakteristike zahvaljujući njihovu određenju od strane najznačajnijih hrvatskih i talijanskih jezikoslovaca. I sama klasifikacija uzvika, na osnovi proučavanih literatura, ukazuje na sličnosti tih konvencionalnih jezičnih znakova velikog stupnja samostalnosti, ali i na stanovite razlike.

\subsection{Definicija uzvika u hrvatskim i talijanskim gramatikama}

Još u najranijim izdanjima hrvatskih gramatika uzvici se definiraju kao vrsta riječi kojima se izražavaju osjećaji, tj. različita stanja duše kao što su: tuga,

\footnotetext{
${ }^{1}$ Primjer je izvorni iskaz preuzet s http://www.sagarana.it/rivista/numero5/saggio7.html (17. 6. 2017.): Sullo scrivere "...chi non sa comunicare o comunica male, e infelice e spande infelicità intorno a sé"... "se non si è chiari non c'è messaggio affatto..." koji je prevela autorica.

${ }^{2}$ Primjer je izvorni iskaz preuzet s http://www.mhdz.hr/index.php/novosti/513-meunarodni-dan-materinjeg-jezika-obiljeen (3. 8. 2019.).
} 
sreća, bijes i sl. (Appendini, 1808; Della Bella, 1728; Kašić, 1604; Starčević, 1812) i odnos govornika prema sugovorniku (Tadijanović, 1761), a ta je definicija u hrvatskim gramatikama uvriježena i danas (Babić i sur., 1991; Brabec, Hraste i Živković, 1954; Maretić, 1963; Silić i Pranjković, 2007; Težak i Babić, 2000). Pojedini su gramatičari u svojim djelima kategoriju uzvika opisali na temelju sintaktičkih kriterija (Della Bella, 1728; Kašić, 1604; Starčević, 1812), definirajući imperative, vokative, optative i poticajne konstrukcije kao korijene i to najčešće $u$ tvorbi glagola ili neoglagoljenih predikata (Katičić, 2002) i imenica (Pintarić, 2002), ali i objekta (Formoso, 1840; Katičić, 2002; Poggi, 1995; Silić i Pranjković 2005). Za uzvike se u pojedinim gramatikama ističe da nemaju vezu s rečenicom, već su izvan nje, a jedna riječ može predstavljati cijelu rečenicu (Mažuranić, 1859; Poggi, 1981) ili su najčešće svojevrsna zamjena za uskličnu rečenicu (Brlić, 1850; Kovačević, 2008; Renzi, Salvi i Cardinaletti, 2001; Serianni, 1988; Težak i Babić, 2000: 317). Kako bi se naglasila prozodičnost pisanog govora $\mathrm{u}$ tekstu, zajedno s interpunkcijskim znakovima, često se koristi verba dicendi, glagoli govorenja kojima se izražava čin govorenja, tj. koji mogu biti nositelji pozitivnih ili negativnih naboja.

I u talijanskim gramatikama uzvici se definiraju kao nepromjenjiva vrsta riječi koja sa semantičko-pragmatičkog aspekta izražava stanje duše: snagu osjećaja, ljubavi, ljutnje, želje, čuđenja, a koja naglašava potvrdu, negiranje, zamolbu (Dardano i Trifone 1997; Formoso, 1840; Fornaciari, 1882; Minisci, 2005; Poggi, 1981; Renzi, Salvi i Cardinaletti, 1995; Sensini, 1997; Serianni, 1988; Trombetti, 1918). Uzvici su „riječi-rečenice“, skup glasova koji mogu izraziti kompletan govorni čin (Minisci, 2005; Poggi, 1981; Renzi, Salvi i Cardinaletti, 1995), karakteristični na prvom mjestu za kolokvijalni govor, a koristeći se holofrastičkim govorom, kao osnovom ekonomičnosti, leksička jedinica dobiva značenje cijele rečenice. U pisanom izražavanju zanos, ekspresivnost i neposrednost izraženi su uskličnikom koji naglašava izrazito emfatičan ton (Dardano i Trifone, 1997, Patota, 2003) i upitnikom kako bi značenje uzvika bilo jasnije (iskazivanje iznenađenja, zbunjenosti, nevjerice) ili zbog naglašavanja faktične, tj. stvarne uloge koju ima u određenom kontekstu (Dardano i Trifone, 1997; Patota, 2003; Sensini, 1997; Serianni, 1988). Važna je i činjenica da pojedini gramatičari analizom sa sintaktičkog aspekta otkrivaju da uzvici mogu sadržavati osobnu zamjenicu u akuzativu kao dometak (Formoso, 1840; Poggi, 1995), a mogu biti dopuna različitim službama riječi kao što su imenice, pridjevi, glagolski oblici, prilozi (Minisci, 2005; Poggi, 1995; Sensini, 1997; Treccani, 201233). Kako bi se naglasila prozodičnost pisanog govora $\mathrm{u}$ tekstu, zajedno s interpunkcijskim znakovima često se koriste glagoli govorenja (verba dicendi) kojima se izražava čin govorenja, tj. koji mogu biti nositelji pozitivnih ili negativnih naboja.

\footnotetext{
${ }^{3}$ http://www.treccani.it/vocabolario/interazione/ (16.2.2017.)
} 


\subsection{Klasifikacija uzvika u hrvatskom jeziku i talijanskom jeziku}

U hrvatskim gramatikama uzvici se dijele u tri skupine: prvu skupinu čine uzvici u užem smislu (Raguž, 1997; Silić i Pranjković, 2007), tj. impulzivni (Silić i Pranjković, 2007) ili primarni uzvici (Simeon, 1969) kojima se izražavaju osjećajna stanja i raspoloženja (jao, ah, oh...), a nisu homonimni drugim vrstama riječi. Ti su uzvici ponajprije jednosložni (joj, fuj, uh...), a mogu biti udvojeni pri čemu se pišu sa spojnicom (ha-ha, hu-hu...). Budući da njihovo značenje ovisi o kontekstu, ta je skupina uzvika višeznačna. Drugu skupinu čine uzvici u širem smislu koji mogu biti homonimni nekoj drugoj skupini riječi (Barić i sur., 1997; Raguž, 1997), a čine ju zapovjedni (imperativni) uzvici (Silić i Pranjković, 2007) ili sekundarni (Katičić, 1991). Koriste se pri obraćanju sugovorniku i vrlo su slični vokativu. Naredbe mogu biti usmjerene prema ljudima, ali i prema životinjama predstavljajući fonološke pojave izvan jezičnog sustava (muc-muc; mic-mic; iš...). I kod tih uzvika značenje ovisi o kontekstu, a akcent je na njihovoj jednoznačnosti. Mogu biti jednosložni (oj, hej...), ali i dvosložni (halo, juhu...). Skupini tih uzvika pridružuju se i poticajne čestice (hajde, gle) kao i čestice s posebnom semantičko-sintaktičkom funkcijom (eno, eto, evo) (Barić i sur., 1997; Katičić, 1991; Maretić, 1963; Silić i Pranjković, 2007). U treću skupinu ubrajaju se onomatopejski uzvici (Silić i Pranjković, 2007) koji oponašaju zvukove, tj. predstavljaju signale koji proizlaze iz komunikacije među ljudima (mljac, cmok...), životinjskog glasanja (ciju-ciju; kre-kre...), oponašanja zvukova u prirodi (fiju, pljas), predmeta (tras, dum...) ili uređaja (tik-tak, din-don...). Neki jezikoslovci onomatopeje ne smatraju uzvicima, već posebnom jezičnom pojavom (Samardžija, 2003), dok ih drugi uvrštavaju u supkategoriju uzvika (Barić i sur., 1995; Barić i sur., 1997; Težak i Babić, 1992).

$\mathrm{U}$ talijanskim gramatikama uzvici se dijele u tri grupe. Posebnu grupu uzvika zbog svoje polisemične prirode čine pravi uzvici (interiezioni vere e proprie) (Dardano i Trifone, 1997; Formoso, 1840; Fornaciari, 1882; Sensini, 1997), tj. primarni uzvici (primarie) (Serianni, 1988) ili jednoznačnice koje imaju holofrastičko značenje (Poggi, 1981; Poggi, 1995). Oni su sličniji instinktivnom poviku nego pravoj riječi, a mogu biti sastavljeni od jednog samoglasnika koji slijedi slovo $h$, a ima samo grafičku vrijednost (oh! uh!...), dok su drugi jednosložni uzvici sastavljeni od samoglasnika ili suglasnika, a karakterizira ih također upotreba slova $h$ (ohi! ahó! bah! mah!...). Pojedini su uzvici leksikalizirani te se razlikuju oni koji su sastavljeni od osobnih zamjenica (ohimé! ahinoi!...) i oni sastavljeni od dvosložnih oblika (ehilà! puah..!) (Sensini, 1997). Drugu grupu uzvika čine nepravi uzvici (interiezioni improprie) (Dardano i Trifone 1997; Formoso, 1840; Fornaciari, 1882; Sensini, 1997), tj. sekundarni uzvici (secondarie) (Serianni, 1988) ili višeznačnice koje mogu imati holofrastičko i leksičko značenje (Poggi, 1981; Poggi, 1995). Te su riječi (imenice, pridjevi, glagolski oblici, prilozi) u funkciji uzvika, a često se 
koriste kao poštapalice samostalno ili unutar rečenice pri izražavanju ljutnje (Accidenti!; Managgia!), čuđenja (Caspita!), entuzijazma i ohrabrenja (Bravo!; Coraggio!), zapovijedi (Basta!; Zitto!), prijekora (Vergogna!)... U govornoj komunikaciji pogrdne riječi i kletve kao poštapalice predstavljaju uzvike koji se nazivaju psovke (bestemmie). U treću skupinu ubrajaju se usklični izrazi ili naprosto kratke rečenice koje imaju ulogu uskličnih rečenica (Santo cielo!; $\mathrm{Va}^{\prime}$ al diavolo!; Al ladro!...). Često, kako se ne bi povrijedili osjećaji drugih osoba ili zbog religioznih razloga, izmišljaju se uzvici vezani za rimska božanstva (Per Giove!; Per Ercole!; Per Bacco!...). Pojedine kletve koje zamjenjuju sramotne riječi (Cavoli!) u potpunosti se razlikuju od onoga što se njima uistinu želi reći.

\section{ISTRAŽIVANJE}

Osnovni je cilj ovoga rada utvrditi glavna obilježja uzvika na hrvatskom i na talijanskom jeziku, posebice sličnosti i razlike na temelju grafemske, semantičke i sintaktičke analize u komunikaciji kao procesu razmjene informacija preko sustava znakova u WhatsApp porukama. Polazna je pretpostavka da uzvici u pisanim porukama govornika hrvatskog i talijanskog jezika izlaze iz uobičajenih normi grafijske transkripcije fonema i pretvaranja slobodnoga skupa riječi u vezani te da su u pisanim porukama većinom prisutni primarni uzvici, tj. uzvici u užem smislu, dok prisutnost sekundarnih uzvika, tj. uzvika u širem smislu nije učestala zbog ekonomičnosti. Stoga se pretpostavlja da su razlike na grafijskoj razini u pisanju uzvika između ta dva jezika vidljive. Druga je pretpostavka da u oba jezika postoji velika sličnosti na semantičkom i sintaktičkom polju.

\subsection{Metodologija}

Istraživanje je provedeno na Sveučilištu u Zadru tijekom akademske godine 2017./2018. U istraživanju je sudjelovalo šezdeset ispitanika i to trideset studenata Odjela za talijanistiku Sveučilišta u Zadru u dobi od 20 do 25 godina i trideset ispitanika iste životne dobi, njihovih prijatelja i rodbine, koji žive u Hrvatskoj i Italiji. Istraživanje je uključilo 30 ispitanika kojima je hrvatski materinski jezik te isti toliki uzorak od 30 ispitanika kojima je materinski jezik talijanski.

Tijekom istraživanja studenti Odjela za talijanistiku Sveučilišta u Zadru bili su zamoljeni da tijekom tjedna pošalju 2 do 3 WhatsApp poruke, njihove osobne i poruke njihovih prijatelja i rodbine, te je prikupljeno ukupno 367 poruka, a izdvojeno njih 189 koje se odnose na uzvike. Prikupljanje poruka nije bilo anonimno kako bi studenti mogli dešifrirati pojedine akronime i objasniti značenje pojedinih poruka u kontekstu. 
Sadržaj WhatsApp poruka prikupljen je u word formatu koji su ispitanici kopirali s mobilnih uređaja šaljući ih na određenu e-adresu. Za analizu su uzete u obzir samo one poruke $u$ kojima je zastupljena navedena lingvistička kategorija, uzvici, sa svrhom utvrđivanja sličnosti i razlika u grafiji kao i na semantičkoj i sintaktičkoj razini u hrvatskom i talijanskom jeziku.

\subsection{Rezultati istraživanja}

Većinu uzvika činila je primarna skupina ili uzvici u užem smislu kao što se i pretpostavilo, a analizirani su samo oni koji su se u većem postotku pojavljivali u porukama na oba jezika kao i pojedini sekundarni i onomatopejski uzvici. Sukladno tome, provedena je grafijska analiza uzvika u oba jezika kao i njihova podjela i analiza sa sintaktičkog i semantičkog stajališta.

Najučestaliji su primarni uzvici (uzvici u užem smislu, pravi uzvici) koji imaju istu grafiju i jednaki su na semantičkoj razini, ali i oni koji ukazuju na semantičku različitost. Slijedi skupina primarnih uzvika koji imaju različitu grafiju, ali isto značenje. Sekundarni su uzvici zastupljeni u nešto manjem broju što pokazuje tendenciju prema ekonomičnosti izražavanja $u$ komunikaciji WhatsApp porukama.

\subsubsection{Grafijska analiza uzvika}

U grafijskoj analizi uzvika WhatsApp poruka u hrvatskom i talijanskom jeziku uočene su mnoge sličnosti, ali i razlike. Pojedini uzvici grafijom samo približno nalikuju glasovima drugih vrsta riječi. Budući da čovjek reproducira glasove koji se ne mogu izraziti $u$ pisanom obliku, često se pribjegava interpunkcijskim znakovima i emotikonima kao vrsti slikovnih signala neverbalne komunikacije koji pomažu u definiranju emocija, raspoloženja i stavova pošiljatelja ili primatelja ili se njihovo značenje tumači u kontekstu.

U pisanim porukama na hrvatskom i talijanskom jeziku, pri uporabi uzvika, u grafiji su uočene mnoge razlike, ali i sličnosti.

a) Prva razlika koja se može uočiti jest uporaba grafema „, h“, tj. u porukama na hrvatskom jeziku na početku ili na kraju uzvika, koji su najčešće jednosložni i istoznačni onima u talijanskom jeziku, u većem se broju slučajeva grafem „h“ izostavlja (1 i., ii., iii.), ali može biti i prisutan (1 iv., v.):

(1) i. Eeee, koja je to glupača, mogla sam i misliti!

ii. Ooooooooo kako sam sretna zbog njega, zaslužio je!

iii. aaaa kako bih se tila vratiti u split!

iv. ah, točno tako kako ti kažeš!

v. Oh...kako ćeš sada bez cime...

U talijanskom jeziku uočljiva je prisutnost grafema $h$ (2 i., ii, iii), koji se ne izgovara, ali se nalazi u svim navedenim uzvicima kao dijakritički znak kako 
bi se razlikovao od veznika (ma- „ali“; $o-$, ,ili“; $e-$ „i“"...) (2 i., ii., iv.) ili od prijedloga ( $a$ - odgovara dativu) (2 iii.):

(2) i. Eh, nn ci posso crdr...

Eh, non ci posso credere...

hrv. Eh, ne mogu vjerovati...

ii. Oh....m dspctnt...

Oh....mi dispiace tanto...

hrv. Oh...jako mi je žao...

iii. ah, potessi ank'io tror 1 lavoretto!

ah, potessi anch'io trovare un lavoretto!

hrv. Ah, da barem ja mogu naći neki poslić!

iv. ehhhh? nn ho cpt nulla!

ehhhh? non ho capito nulla!

hrv. heeeej? Nisam ništa shvatio!

b) Pojedini uzvici premda istog značenja imaju potpuno različite grafijske oblike. U porukama na hrvatskom jeziku učestala je uporaba grafema , ,j" (3 i., ii.), a grafem "h” najčešće se pojavljuje na početku uzvika (3 iii., iv.):

(3) i. Ajoj opet me muči umnjak, ako ga ne izvadin sama neće niko!

ii. fuj, a smrde li ove ribe, sutra idem u menz

iii. Hmmm pa nismo se baš tako dogovorili...

iv. Hehehe ti si neporavljiv, zaboli te!

U talijanskom jeziku grafem $h$ vrlo je frekventan na kraju (4 i., iii.) ili u sredini riječi (4 ii., iii.):

(4) i. Poh, che cattivo sapore in bocca dp sta sigaretta!

Poh, che cattivo sapore in bocca dopo questa sigaretta! hrv. Fuj, kako je ružan okus u ustima nakon ove cigarete!

ii. Ahi $m$ sn fatta una bruciatura con la pstr $X$ i capelli

Ahi, mi sono fatta una bruciatura con la piastra per i capelli hrv. Ajoj, opekla sam se na peglu za kosu!

iii. Eheheheheheh, 6 davvero caduta dalle scale, ma scherzi, no???!

Eheheheheheh, sei davvero caduta dalle scale, ma scherzi, no???! hrv. Hahahahaha, stvarno si pala sa stepenica, šališ se, zar ne????!

c) Prisutni su i istoznačni uzvici iste grafije u oba jezika (mmmmm, uh, pst...). Primjeri u oba jezika slijedom izražavaju gastronomski užitak (5 i., 6 i.), neugodu - umor (5 ii., 6 ii.), dozivanje (5 iii., 6 iii.):

(5) i. kako sam dobru paštu spremila, mmmmm!

ii. Uh, toliko sam umorna, včrs ću zaspati u $8 \ldots$

iii. Pst, nemoj im popustiti, nađi neki sistem... 
(6) i. Mmmmm ke fame!

Mmmmm che fame!

hrv. Mmmmm kako sam gladna!

ii. Uh, che caldaccio nn poxo neanke respirare!

$\mathrm{Uh}$, che caldaccio non posso neanche respirare

hrv. Uh, koje li nesnosne vrućine ne mogu ni disati!

iii. Pst, sei sola?

iv. hrv. Pst, jesi li sama?

d) Intonacija se nadomješta upotrebom velikih slova $u$ porukama na oba jezika (7 i., 8 i.):

(7) i. HEJ! Jesi rezentala kosu?

(8) i. EHI! nn poxo trovare la ricetta ke mi ai inviato hrv. HEJ!ne mogu pronaći recept koji si mi poslala.

e) Umnožavanjem grafema i ponavljanjem rečeničnih znakova naglašava se jačina pozitivnih ili negativnih naboja koji prate neku poruku i na hrvatskom i na talijanskom jeziku (9 i., ii., 10 i., ii.):

(9) i. Jos ti javim vers. Cmokkk!.;c Još ti javim večeras. Cmokkk!.;c

ii. HEEEEEJ! Jesi rezentala kosu?

(10) i. Uaoooo! xke nn me l ai detto prima?

Uaoooo! perché non me l'hai detto prima?

hrv. Uauuuu! zašto mi to nisi rekla prije?

ii. EHIIIIIIIIII!nn poxo trovare la ricetta ke mi ai inviato settimana scorsa.

EHIIIIIIIIII!non posso trovare la ricetta che mi hai inviato settimana scorsa.

hrv. HEEEEEEEJ! ne mogu pronaći recept koji si mi poslala prošli tjedan.

f) Upotreba tri točke na kraju rečenice može izražavati nesigurnost (11 i., 12 i.):

(11) i. Ha... bija bi onda drugačiji

(12) i. Eh, pensaci...

hrv. Eh, zamisli... 
g) U grupi uzvika koji se odnose na dozivanje prevladavaju imperativni uzvici u porukama na oba jezika koji su obično jednosložni ili dvosložni (13 i., 14 i.):

(13) i. Ej di si????

(14) i. Oh, cara come va? hrv. Hej, draga kako si?

\subsubsection{Sintaksa uzvika}

Sintaksa uzvika vrlo se rijetko spominje u znanstvenim radovima, a njihova se analiza zasniva ponajprije na semantičko-pragmatičkim karakteristikama. Prema nekim jezikoslovcima uzvici su lišeni sintaktičkih veza s drugim riječima u rečenici i nisu dijelovi rečenice (Babić i sur., 1991.; Barić i dr., 1997; Katičić, 1991; Maretić, 1963; Patota, 2003; Poggi, 1995; Silić i Pranjković, 2005; Simeon, 1969b), a odgovaraju govornom činu (Poggi, 1995). Uzvici se ne povezuju s ostalim riječima u rečenici, ali postoje primjeri u kojima otvaraju mjesto različitim rečeničnim dijelovima, tj. oblicima nominativa, dativa i akuzativa i u porukama na hrvatskom i na talijanskom jeziku.

a) Uz uzvike koji se tvore pomoću pridjeva može se nalaziti nominativ (15 i., 16 i.):

(15) i. Jadni mi sutra, 2 kolokvija i 1 ispit!!!!!

(16) i. beata lei, l'ha superato.... hrv. blago njoj, položila ga je....

b) U WhatsApp porukama u oba jezika susrećemo i ostale oblike od kojih neki mogu poprimiti i funkciju glagola (17 i., 18 i.):

17) i. Jao si ga tebi ako me včrs ne odvedeš na pizzu! Jao tebi ako me večeras ne odvedeš na pizzu!

18) i. Ahimé sno troppo care $X$ le mie tasche! Ahimé sono troppo care per le mie tasche! hrv. Ajme/Ajme meni previše su skupe za moj džep!

c) U funkciji glagola mogu biti i prezentativi „eto", „evo“ i „eno“" (19 ii., iii., iv., 20 i.). Ono što se može zamijetiti jest to da je u talijanskom jeziku oblik ecco ekvivalentan po značenju oblicima „evo“ i „eno“ u hrvatskom jeziku. Njihova je učestalost u porukama i različitost zamjetnija u hrvatskom jeziku: 
(19) i. Rekla je u detalje, a rom. ima 356 str. blago nama!

Rekla je u detalje, a roman ima 356 stranica blago nama! ii. šaljem ti odmah...evo ti!

iii. eto mu pa nek sam sd piše esej

eto mu pa nek' sam sada piše esej

iv. eno joj sad daleko će dogurati kad stalno pametuje

(20) i. Eccomi!sn appena uscit dall'aula

\section{Eccomi! Sono appena uscita dall'aula}

hrv. Evo me ! tek sam izašla iz predavaonice

d)Uzvik može biti u službi predikata odnoseći se ponajprije na onomatopejske uzvike (21 i., 22 i.):

(21) i. Onda mu je fljas opalila jednu iz volea da više nije znao kako se zove!

(22) i. Da noi c'era un temporale molto forte, le finestre sbattevano costantamente bum bum

hrv. Kod nas je bilo jako nevrijeme, prozori su lupali neprestano bum bum

e) Osim u službi predikata, u porukama na hrvatskom i talijanskom jeziku uzvik se pojavljuje i u službi subjekta (23 i., 24 i.):

(23) i. kome je taj hihihihi bio upućen, a?

ii. kad sam čla ups znl sm da je zabrljao

\section{kad sam čula ups znala sam da je zabrljao}

(24) i. ho detto pfui quando l'ho visto bere

hrv. rekla sam fuj kada sam ga vidjela kako pije

f) Od vokativnih uzvika koji se susreću u porukama na hrvatskom i talijanskom jeziku najčešći su „hej“/ "ej" - ehi; ,ps" (25 i., ii., iii., 26 i., ii.):

(25) i. Di ste svi, ojjijj!

ii. ps! daj pošalji mi onu skriptu

iii. Alo!!!! Jesi živa?!

(26) i. Oh, allora ke ne dici?

Oh, allora che ne dici?

hrv. ej, onda što kažeš o tome?

ii. dove andiamo? .....ps!

hrv. gdje idemo?....ps! 
Može se primijetiti da se u porukama na hrvatskom jeziku za razliku od talijanskoga za pozivanje primatelja na komunikacijski čin susreću uzvici „alo“ $\mathrm{i}$ „„oj", dok se u talijanskom jeziku koristi uzvik oh, a ekvivalenti za uzvik ehi jesu „hej“ i „ej“, dok se identičan grafijski oblik uzvika „ps“ koristi u oba jezika.

\subsubsection{Semantika uzvika}

Riječi se mogu podijeliti na punoznačnice (autosemantične riječi) u koje se ubrajaju imenice, pridjevi, prilozi, glagoli, brojevi, tj. one riječi koje ne ovise o sintaktičkim vezama i nepunoznačnice (sinsematične riječi), tj. funkcionalne riječi koje značenje dobivaju tek $u$ kontekstu, a tu se uz zamjenice, prijedloge i veznike ubrajaju i uzvici, deiktičke riječi što znači da su interpretirane sa stajališta pošiljatelja i kontekstne situacije. Nepunoznačnice, kao i punoznačnice, prema pojedinim gramatičarima imaju gramatičko značenje (De Rienzo, 2006; Poggi 1995; Samardžija, 1988), i tu se u prvom redu misli na primarne uzvike, ali mogu imati i leksičko značenje (Pranjković, 1999), tj. pripadati leksičkom sustavu (Poggi, 1995) što je karakteristika sekundarnih uzvika. Osim konteksta, intonacija ima vrlo važnu ulogu u interpretaciji uzvika, a u WhatsApp porukama ostvaruje se ovisno o njihovu položaju u rečenici, rečeničnom znaku koji iza njih slijedi, ali i prisustvo emotikona važan je čimbenik za njihovo semantičko određenje. Stoga se kaže da pojedini uzvici mogu biti višeznačni. No, unatoč višeznačnom i multifunkcionalnom karakteru koji ovu skupinu riječi čini specifičnom, neki uzvici ponajprije služe za izražavanje samo određene ilokucijske vrijednosti. U ovom su poglavlju sa semantičkog stajališta analizirani uzvici koji se najučestalije javljaju u porukama u oba jezika i oni koji ukazuju na sličnosti i razlike $u$ njihovoj interpretaciji. U sljedećim WhatsApp porukama isti uzvici i na hrvatskom i na talijanskom jeziku mogu se parafrazirati na različite načine, pri čemu je iznimno važna kontekstualna situacija, jer na taj način kod uzvika u potpunosti dolazi do izražaja njihov deiktički karakter.

a) Polisemičnost se $u$ oba jezika ponajprije susreće kod uporabe primarnih uzvika, a u primjerima su izdvojeni oni najučestaliji. Uzvik „ah“ u velikom broju može se susresti u oba jezika, no u porukama na hrvatskom jeziku često se pojavljuje u obliku grafema "a“. Njime se može izraziti žaljenje (27 i., 28. i.), iznenađenje (27 ii., 28 ii.), ironičnost (27 iii., 28 iii.), ljutnja (27 iv., 28 iv.), čuđenje ( $27 \mathrm{v}$.$) :$

(27) i. Ah, ono što ja osjećam ne želim nikome... (ah = teško mi je)

ii. aaaaaa, koje ludilo doša je!!!! (ah = super)

iii. kako se samo pravimo pametni, ah! (ah = zamisli)

iv. a, ma pusti je uvik nšt blebeće pa opet bude po mome $(\mathrm{ah}=\mathrm{baš}$ me briga)

v. aaaaaaaaa, kako je bezobrazna nisam se nadala da je tako bahata (aaaaaaaaa $=$ čudim se) 
(28) i. Ah! Non ci $6 \ldots(a h=m i$ sento triste $)$

Ah! Non ci sei...

hrv. Ah! Nema te...

ii. Ah, vrmnt? non sapevo che lui fosse andt da lucia! ( $a h=$ ma dai $=$ ma daj)

Ah, veramente? Non sapevo che lui fosse andato da lucia!

hrv. Ah, stvarno? Nisam znala da je on otišao kod lucije!

iii. Ah, mi fai morire dal ridere! ( $a h=$ non sei affatto interessante = stvarno si nezanimljiv)

hrv. Ah, umrijet ću od smijeha!

iv. ah, ke cazzo vuole da me, sn stanchixima (ah = che mi lasci in pace

= neka me više ostavi na miru)

\section{ah, che cazzo vuole da me, sn stanchixima}

hrv. ah, koji k.... želi od mene, jako sam umorna

v. ah ah ah ah ha totalmente dimenticato l'appunto, roba da matti!!!! (ah= è ridicolo $=$ smiješno $\mathrm{mi}$ je )

hrv. ha ha ha ha posve je zaboravio na sastanak, za poludjeti!!!!

Ono što se može vidjeti iz primjera jest to da se uzvik „ah" interpretirajući smijeh $\mathrm{u}$ talijanskom jezik razlikuje $\mathrm{u}$ grafijskom obliku $\mathrm{u}$ odnosu na isti uzvik u hrvatskom jeziku.

b) Premda uzvik „eh“ može imati različita semantička značenja ovisno o kontekstu, u hrvatskom se jeziku u porukama, osim u spomenutom obliku (29. iii) gdje se naglašava negiranje, susreće češće kao grafem „e" (29 i., ii., iv.), vrlo često redupliciran ( 29 i., iv.), a koristi se za izražavanje nesigurnosti (29 i.), žaljenja (29 ii.) ili blage prijetnje (29 iv.):

(29) i. E nezz, nadan se da joj ni nista. ( $E=$ nisam baš siguran)

ii. Eeeee da mogu vratiti vrijeme unazad... (Eeeee $=$ Tako bih voljela $)$ iii. Eh, moš mislit što sam prestala, onda lupam po čokolatinima (Eh = Kako da ne)

iv. eeeeeee nećeš proći baš lišo (eeeeee= pazi se/ mislim da)

Uzvik eh u porukama na talijanskom jeziku koristi se najčešće za izražavanje ili traženje potvrde (30 i.), zahtjeva za ponavljanje prethodno napisanog sadržaja od strane pošiljatelja zbog poteškoća u razumijevanju (30 v.), za izražavanje dozivanja (30 ii., 30 v.), čuđenja (30 iv.), izbjegavanje odgovora (30 iii.): 
(30) i. L'ha fatto, eh? (eh= è vero = zar ne $)$

hrv, učinio je to, zar ne?

ii. Cm poxo farlo? Nn ho cpt bene....Eh?:O (Eh= Mi senti?! = Čuješ li me ?!)

Come posso farlo? Non ho capito bene... Eh?:O

hrv. Kako ću to učiniti? Nisam dobro shvatila....hej?

iii. A: me lo dirai o no???????

B: Eh.... (Eh... = Allora... = Pa ovaj...)

hrv. A: hoćeš li mi reći ili ne????????

B: Pa ovaj...

iii. Eh, non ci posso credere... te l'ha buttata via?! $($ Eh $=$ Incredibile $=$ Nevjerojatno)

hrv. Stvarno, ne mogu vjerovati... izbacila te/ potjerala te iz kuće?!

v. Eh, puoi spiegarmelo ankora $1 \mathrm{vlt!} \quad($ Eh $=$ Ti prego di ripetermelo /

Non l' ho capito bene/ Ehi = Molim te ponovi/ Nisam dobro shvatio/ Hej)

Eh, puoi spiegarmelo ancora una volta!

hrv. Molim te, ponovi mi još jednom!

c ) Uzvik „hej” osim u tom obliku (31 i.) u hrvatskom se jeziku u porukama još češće pojavljuje s izostavljenim grafemom „h" (31 ii.) ili samo u obliku grafema „e $\mathrm{e}^{\prime \prime}$ (31 iii.). U porukama na talijanskom jeziku isti uzvik susreće se u obliku uzvika ehi (32 i., ii.), ali i u obliku uzvika eh (32 ii.):

(31) i. Hej! Si mi se oporavila? $($ Hej = Bog! = pozdrav $)$

ii. Ej! Pretjerala si ovaj put i to dobrano $(E j=N i j e$ to dobro $=$ prigovor $)$

iii. Hoćemo li u Gume ekipa, eeeeee? (eeeeee = čujete li me? = obraćanje):

(32) i. ehi, ke succede là? (ehi = c'ê qualcuno = ima li koga = dozivanje)

ehi, che succede là?

hrv. hej što se tamo događa?

ii. ehi ecco le scarpe ke ho cmprt ieri dopo lzn (ehi = guarda = pogledaj)

ehi ecco le scarpe che ho comprato ieri dopo lezioni

hrv. hej evo cipela koje sam kupila jučer nakon predavanja

iii. Nn cpsc a ki l'hai dato? Eh? (Eh? = Vuoi ripetermelo? = Hoćeš li mi ponoviti?)

Non capisco a chi l'hai dato? Eh?

hrv. Ne razumijem kome si ga dala? Hej? 
d) Uzvik „oh“ na hrvatskom jeziku (33 i.) kao i oh na talijanskome (34 i.), kao što je već prethodno rečeno u poglavlju o grafijskoj analizi uzvika, nerijetko se koristi pri izražavanju žaljenja, a u porukama na hrvatskom jeziku najčešće se javlja kao samostalan grafem "o“ izražavajući i neugodno iznenađenje, dok je u porukama na talijanskom jeziku grafem $h$ uvijek prisutan:

33) i. Oh, a baš sam se nadala da ćeš proći. $(\mathrm{Oh}=$ Šteta = žaljenje $)$

ii. o... stvarno mu nije ok a da ti njemu vratiš istom mjerom? $(\mathrm{o}=\mathrm{ma}$ zamisli = neugodno iznenađenje)

34) i. Ohhh, ma nn posso dirtelo xke Mauro nn me lo permette. (Oh=Mi dispiace $=$ žaljenje)

Ohhh, ma non posso dirtelo perché Mauro non me lo permette. hrv. Oprosti, ne mogu ti to reći jer mi Mauro ne dopušta.

ii. Oh, congratulazioni! (oh= com'ê bello = kakvo lijepo iznenađenje) hrv. Oh, čestitam!

Uzvik „o“ u redupliciranom obliku pojačava intenzitet onoga što se želi reći (35i.) kao i redupliciranje grafema $h$ (36i.) u porukama na talijanskom jeziku. Isti se uzvik u porukama na hrvatskome pojavljuje kao „ooho":

(35) i. oooo, da je barem lito... (oooo = tako bih voljela = želja $)$

ii. ooho, u široke smo se gaće obukli!??! (ooho = je li = ironičnost)

(36) i. ohhh, fossi tu mia sorella $(o h=$ sarebbe bello $=$ kako bi bilo lijepo = želja $)$ hrv. ohhh, da si mi barem ti sestra

e) U porukama na oba jezika susrećemo uzvike koji imaju isto semantičko značenje, ali potpuno različitu grafiju među kojima se susreće uzvik ok (37 i.) kao posuđenica iz engleskog jezika u porukama, a na hrvatskome odgovara uzviku be (kratica od priloga bene) u porukama na talijanskom jeziku bilo kao potvrda (38 i.) ili pojačavanje pitanja u oba jezika (37 ii., 38 ii.):

(37) i. ok, morat ćemo završiti esej do petka (ok = u redu)

ii. sutra me podsjeti pa ti pošaljem sažetak, ok?

(38) i. be', facciamolo insieme $\left(b e^{\prime}=\right.$ va bene $=\mathrm{u}$ redu $)$

hrv. ok, napravit ćemo to zajedno

ii. be' e dmn ci sentiamo alle $8 ? \quad\left(b e^{\prime}=\right.$ quindi $=$ dakle $)$

be' e domani ci sentiamo alle 8 ?

hrv. dakle sutra se čujemo u 8 ? 
f) Za izražavanje nezainteresiranosti i nesigurnosti u hrvatskom jeziku uočava se frekventnost uzvika „ma“ (39 i.), dok se u porukama na talijanskom jeziku susreće uzvik mah (40 i., ii.):

(39) i. A: daj, bit će sve ok ob!

B: ma... što ja znam $(\mathrm{ma}=$ nisam sigurna $=$ nesigurnost $)$

(40) i. A: Non avere paura! Sei bravissima!

B: Mah... (mah = non sono sicura = nesigurnost $)$

hrv. A: ne boj se! Odlična si!

B: Nisam baš sigurna...

ii. A: perke non gli rispondi? $\quad(m a h=$ non ho voglia $=$ ne da $\mathrm{mi}$ se $=$ nezainteresiranost)

B: mah....
A: perché non gli rispondi?
B: mah...
hrv. A: zašto mu ne odgovoriš?
B: ma...

g) Uzvik talijanskog porijekla bravo u hrvatskom jeziku je nepromjenjiv (41 i.), dok se u talijanskom jeziku mijenja s obzirom na rod i broj sudionika u pisanom komunikacijskom procesu kojem se pošiljatelj obraća (42 i.). U porukama na oba jezika često ima i negativnu konotaciju izražavajući ironiju (41 ii., 42 ii.), ali i upozorenje (41 iii., 42 iii.):

(41) i. Bravo! Dobro si joj skresala u facu! (bravo = svaka čast $=$ ponos $)$

ii. ma bravo tek si sada napravila glupaču od sebe (bravo=katastrofa)

iii. Bravo, bravo, samo se vi igrajte! (bravo = nije baš pametno)

(42) i. Brava! Sn fiera di te!!!!! (brava= ponos)

\section{Brava!Sono fiera di te!!!!!}

hrv. Bravo! Ponosna sam na tebe!!!!!

ii. brava, brava! Ma perke gliel'hai detto? Lei è una ficanaso!!!!! (brava= sei stupida = kako si glupa)

brava, brava! Ma perché gliel'hai detto? Lei è una ficanaso!!!!!

hrv. bravo, bravo! Ali zašto si joj to rekla? Ona je zabadalo!!!!

iii. bravo, falo di nuovo e nn vorra nemmeno guardarti

bravo, fallo di nuovo e non vorrà nemmeno guardarti :/

bravo, napravi to ponovo i neće te htjeti niti pogledati :/ 


\subsection{Implikacije istraživanja}

WhatsApp poruke kao pisani oblik komunikacije odlikuje neformalni pravopis koji nastaje vrlo spontano. Spajajući znakove i simbole, korisnici su osmislili razumljiv i ekonomičan jezik bez čvrstih pravila prepun neologizama, skraćenica, organskih idioma, posuđenice i skraćenica na engleskom jeziku. Taj novi jezik, spoj tradicionalnog i inovativnosti trebao bi biti proučavan na kolegijima visokih učilišta kako bi se studentima približili kodirani znakovi i kako bi se uvidjele razlike između organskog i neorganskog idioma.

$\mathrm{S}$ druge strane korisnici nastoje pronaći najbolji mogući način kako bi imitirali mimiku, intonaciju, zvukove i uzvike kao sastavni dio govorne komunikacije. Uzvici kao vrsta riječi koja služi za uspostavljanje sintaktičkih i semantičkih odnosa čije je značenje suznačno, tj. uvjetovano kontekstom i naglaskom, predstavljaju ujedno i vrstu riječi koje su samoznačne, tj. leksičke i zbog velikog stupnja samostalnosti predstavljaju cjelovite rečenice. Stoga se postavlja pitanje zašto je ova kategorija zanemarena $u$ tolikoj mjeri. Prema pojedinim hrvatskim znanstvenicima jedan od razloga jest taj što se uzvici najčešće koriste u spontanom i kolokvijalnom izrazu, tj. u svakodnevnoj komunikaciji (Kovačević, 1986) pripadajući dijalektima, idiolektima ili sociolektima. No, upravo to bi i trebao biti jedan od razloga njihova proučavanja budući da u usmenoj, ali i pismenoj komunikaciji doprinose stvaranju prisnosti i pojačavaju emotivni naboj. Osim navedenog, uzvici doprinose stvaranju neologizama, novih logatoma i razlikujući se sa sociološkog i geografskog aspekta, doprinose jezičnom bogatstvu i važan su jezični izvor za proučavanje.

U hrvatskim i talijanskim gramatikama bilo bi iznimno značajno primijeniti jedinstvenu definiciju i klasifikaciju uzvika i posvetiti se njihovu istraživanju na semantičkoj i sintaktičkoj razini zbog njihove već navedene važnosti te stvaranja posebne „obojenosti“ u komunikaciji.

\section{ZAKLJUČAK}

Ono što pisane poruke ponajviše razlikuje od tradicionalnog pismenog izražavanja jest njihova čvrsta veza s govornim jezikom koja obuhvaća vrlo širok spektar oblika izražavanja, a jedan od njih jesu razgovorni znakovi, tj. uzvici. Ta lingvistička kategorija služi da bi se uklonila ograničenja koja stvara oblik pisane komunikacije putem medija. Pojačanu osjećajnost i subjektivno stanje korisnici takvog oblika komunikacije izražavaju uporabom pojednostavljenih i nepromjenljivih riječi koje funkcionalno odgovaraju cijelomu izričaju, a njihov je odabir najčešće odraz svakodnevnog govora i medijskog utjecaja, ponajprije televizije i stripa. 
Osnovni je cilj ovoga rada bio utvrditi glavna obilježja uzvika na hrvatskom i na talijanskom jeziku, posebice sličnosti i razlike na temelju grafijske, semantičke i sintaktičke analize u komunikaciji kao procesu razmjene informacija preko sustava znakova $u$ WhatsApp porukama koje su uočene, izdvojene i posebno klasificirane. Pretpostavka da su grafijske razlike uzvika mnogo izraženije od semantičko-pragmatičke i sintaktičke razlikovnosti pokazala se točnom. Među najfrekventnijim jednosložnim i dvosložnim primarnim uzvicima (uzvici u užem smislu, pravi uzvici) u oba jezika ističu se senzitivni, emotivni - koji se za razliku od senzitivnih osim izražavanja emotivnog naboja odnose i na psihičku sferu, potom impulzivni uzvici kao i oni koji izražavaju ironičnost, nezainteresiranosti pri čemu su mnogi istog značenja i imaju istu grafiju (ah - ,ah" (a); oh - „oh" (o); eh - „eh" (e); pst - „pst“), ali i oni kod kojih se, iako je bilježenje glasova u potpunosti različito, značenje ne mijenja (ahimé - "ajme", poh - „fuj"; ahi - „joj"; boh „hm“). Treću skupinu čine oni koji se grafijski ne razlikuju, ali se razlikuju na semantičkoj razini pri izražavanju negiranja nečega u hrvatskom jeziku i dozivanja ili traženja potvrde u talijanskom jeziku (eh - „eh") ili pri pojačavanju pitanja u oba jezika (be'? - „ok?“). Ono što se može zamijetiti jest to da je u talijanskom jeziku oblik ecco ekvivalentan po značenju oblicima „evo" i „eno" u hrvatskom jeziku. Sekundarni uzvici (uzvici u širem smislu, nepravi uzvici), koji su često ekvivalent samim rečenicama, sa sintaktičkog stajališta poprimili su ulogu pridjeva, glagola, imenica, priloga i vokativnih uzvika izražavajući emocionalnost, ironičnost, oponašanje zvukova, ponos ili dozivanje (,,jadni mi“; beata lei; ",blago nama“; ",eto mu“; „,eno joj"; eccomi; jao tebi; ahimé; ",bum bum“; "hihihihi“; pfui; bravo/brava, "bravo"; ",alo").

Razlika se očituje i u klasifikaciji uzvika. U hrvatskim gramatikama postoje tri podjele. Prva podjela uzvika odnosi se na uzvike u užem smislu, širem smislu i onomatopejske uzvike, dok druga podjela ne obuhvaća onomatopeje. U trećoj podjeli onomatopejski se uzvici uvrštavaju u supkategoriju uzvika. Talijanski gramatičari dijele uzvike na ujednačeniji način klasificirajući ih kao prave ili primarne uzvike, neprave ili sekundarne uzvike i usklične izraze. Upravo zbog različitog razumijevanja ove vrste riječi od strane gramatičara, trebalo bi težiti jedinstvenoj klasifikaciji uzvika koji unutar polja jezične inovacije teži oblikovanju posebnog semantičkogramatičkog sustava tvoreći i neologizme koji postaju prihvatljivi kodovi u oblicima neformalne pisane komunikacije. 


\section{LITERATURA}

Appendini, F. M. (1808) Grammatica della lingua illirica. Ragusa: Antonio Martecchini.

Babić, S., Brozović, D., Moguš, M., Pavešić, S, Škarić I. i Težak, S. (1991) Povijesni pregled, glasovi i oblici hrvatskoga književnoga jezika. Zagreb: HAZU i Nakladni zavod Globus.

Barić, E., Lončarić, M., Malić, D., Pavešić, S., Peti, M., Zečević, V., i Znika, M. (1995) Hrvatska gramatika. Zagreb: Śkolska knjiga.

Barić, E., Lončarić, M., Malić, D., Pavešić, S., Peti, M., Zečević, V., i Znika, M. (1997) Hrvatska gramatika. Zagreb: Školska knjiga.

Brabec, I., Hraste M. i Živković, S. (1954) Gramatika hrvatskoga ili srpskog jezika. Zagreb: Školska knjiga.

Brlić, I. A. (1850) Grammatik der Illyrischen Sprache: wie solche in Bossnien, Dalmazien, Slawonien, Serbien, Ragusa \& c. dann von den Illyriern in Banat und Ungarn gesprochen wird. Ofen: Universitäts Schriften.

Dardano, M. i Trifone, P. (1997) La nuova grammatica della lingua italiana. Bologna: Zanichelli.

Della Bella, A. (1728) Dizionario italiano, latino, illirico. Venecija: Cristoforo Zanne.

De Rienzo, G. (2006) Scioglilingua: Guida alla grammatica italiana. Milano: Rizzoli.

Formoso, S. F. (1840) La grammatica della lingua italiana. Napoli: tipografia di Testa e Chiara, in $8^{\circ}$.

Fornaciari, R. (1882) Grammatica italiana dell'uso moderno: compendiata e accomodata per le scuole. Firenze: Sansoni.

Kašić, B. (1604) Institutionum linguae Illyricae libri duo Rim. Osnove ilirskoga jezika u dvije knjige. Pretisak Köln - Beč 1977., CD Zagreb 2001. Zagreb: 2002., 2. izd.: Zagreb - Mostar, 2005.

Katičić, R. (1986) Sintaksa hrvatskoga književnog jezika. Zagreb: JAZU.

Katičić, R. (2002) Sintaksa hrvatskoga književnog jezika. Zagreb: HAZU i Nakladni zavod Globus.

Kovačević, A. (2008) Uzvici u hrvatskoglagoljskim tekstovima. Slovo: časopis Staroslavenskoga instituta 58, 87-135.

Maretić, T. (1963) Gramatika hrvatskoga ili srpskoga knjižeonog jezika. Zagreb: Matica hrvatska.

Mažuranić, A.(1859) Slovnica Hèrvatska za gimnazije i realne škole. Dio 1, Rěčoslovje. Zagreb: Troškom spisateljevim. Pretisak - Zagreb (2008): Institut za hrvatski jezik i jezikoslovlje.

Minisci, A. (2005) Grammatica italiana. Milano: Edizioni Alpha Test.

Patota, G. (2003) Grammatica di riferimento della lingua italiana per stranieri. Firenze, Le Monnier.

Pintarić, N. (2002) Pragmemi u komunikaciji. Zagreb: Zavod za lingvistiku Filozofskog fakulteta u Zagrebu.

Poggi, I. (1981) Le interiezioni. Studio del linguaggio e analisi della mente. Torino: Boringhieri.

Poggi, I. (1995) Le interiezioni in Renzi, Salvi e Cardinaletti 1988-1995, vol. 3², Tipi di frase, deissi, formazione delle parole. Bologna: Il Mulino, 403-426.

Pranjković, I. (1999) Gramatika Ignjata Alojzija Brlića (opis nepromjenjivih riječi). Jezikoslovlje 2 (1), 170-181.

Raguž, D. (1997) Praktična hrvatska gramatika. Zargreb: Medicinska naklada.

Reardon, K. (1998) Interpersonalna komunikacija: Gdje se misli susreću, Zagreb: Alinea, 13.

Renzi, L., Salvi, G. i Cardinaletti, A. (2001) Grande grammatica italiana di consultazione. Volume I. Bologna: Il Mulino.

Samardžija, M. (2003) Hrvatski jezik 4. Zagreb: Školska knjiga.

Sensini, M. (1997) La grammatica della lingua italiana. Milano: Mondadori.

Serianni, L. (1988) Grammatica italiana.Italiano comune e lingua letteraria. Con la collaborazione di Castelvecchi, A. Torino: Utet Libreria.

Silić, J. i Pranjković, I. (2005) Gramatika hrvatskoga jezika : za gimnazije i visoka učilišta. Zagreb : Školska knjiga.

Silić, J. i Pranjković, I. (2007) Gramatika hrvatskoga jezika za gimnazije i visoka učilišta. Zagreb: Školska knjiga.

Simeon, R. (1969) Enciklopedijski rječnik lingvističkih naziva. II. svezak: P-Ž. Zagreb: Matica hrvatska. 
Sironić-Bonefačić, N. (1996) Uzvici, ideofoni i onomatopeje u talijanskom jeziku. Strani jezici 25 (3-4), 136-146.

Starčević, Š. (1812) Nova ricsoslovica ilircska. Trst: Gaspar Weis. Pretisak: Institut za hrvatski jezik i jezikoslovlje, Zagreb: 2002.

Tadijanović, B. (1761) Svaschta po mallo illiti kratko sloxenye immenah, $i$ ricsih u illyrski, $i$ nyemacski jezik. Magdeburg (Svašta po malo iliti kratko složenje imena i riči u ilirski i njemački jezik). Pretisak: Institut za hrvatski jezik i jezikoslovlje, Zagreb, 2012.

Težak, S. i Babić, S. (1992) Gramatika hrvatskoga jezika: priručnik za osnovno jezično obrazovanje. Zagreb: Školska knjiga.

Težak, S. i Babić, S. (2000) Gramatika hrvatskoga jezika, priručnik za osnovno jezično izražavanje. Zagreb: Školska knjiga. Prerađeno i dopunjeno izdanje, 12.

Trombetti, A. (1918) Grammatica italiana, ad uso delle scuole. Milano... [etc.]: Albrighi, Segati \& C. http://www.sagarana.it/rivista/numero5/saggio7.html (17. 6. 2017.)

http://www.mhdz.hr/index.php/novosti/513-meunarodni-dan-materinjeg-jezika-obiljeen $\quad$ (3. 8. 2019.)

\section{CONTRASTIVE ANALYSIS OF INTERJECTIONS IN ITALIAN AND CROATIAN IN WHATSAPP MESSAGES}

This paper presents a contrastive analysis of interjections in Croatian and Italian with examples used in WhatsApp messages. After the introductory part that refers to the diachronic analysis of the aforementioned category, there is a corpus analysis of interjections with examples from both languages which is aimed at their orthographic, semantic and syntactic similarities and differences.

The analysis of the collected examples was conducted during the academic year 2017/2018 on the sample of 60 respondents, aged between 20 and 25, currently residing in Croatia and Italy. The hypothesis has been proven that most respondents use interjections in the written form imitating the spoken language in the orthographic form. The same interjections do not always have exactly the same meaning in both languages even though their semantic and syntactic features are very similar.

Keywords: interjections, contrastive approach, Croatian and Italian, Whats App messages 